\title{
Dirty habits - a basis for developing sustainable productivity
}

\author{
A.P. RHODES ${ }^{1}$, A.D. MACKAY ${ }^{2}$, M.G. LAMBERT $^{2}$, M.K. KRAUSSE ${ }^{3}$, B.H. WILLIS ${ }^{1}$ \\ and B. WITHELL ${ }^{4}$ \\ ${ }^{1}$ Agriculture New Zealand, PO Box 288, Dannevirke \\ ${ }^{2}$ AgResearch, Private Bag 11008, Palmerston North \\ ${ }^{3}$ Landcare Research, Private Bag 11052, Palmerston North \\ ${ }^{4}$ Agriculture New Zealand, PO Box 841, Palmerston North
}

\begin{abstract}
Farmers have a far reaching impact in influencing the progress that is made in the sustainable management of New Zealand's natural resources. While some advocates are ready and willing to prescribe apparently "more appropriate" behaviour, the contribution to sustainability can be questioned. There is considerable evidence that there is a complex interaction between farmers' knowledge, attitude and behaviour, and economic, personal and community influences that shape the nature and extent of their individual response to the challenge of sustainable resource management. This paper will draw on the experience of working with farmers and community members in the Southern North Island to develop an approach to allow land users to better understand the soil and water resources of the farm. By using this knowledge, and their awareness of issues and values, farmers and community members were better able to consider options, evaluate alternatives, and balance the integration of sustainable resource management, economic, personal and social goals. A strong conclusion of the project was that farmers must have a comprehensive understanding of the soils and land resource of their farm. A feature of the project was the development of the concept of Land Management Units (LMUs) that are aggregations of soil or topographic units with closely related properties that form a practical farm management unit. LMUs provide the basis for evaluating the impact of current policies and management practice, generating ideas, evaluating
\end{abstract}

risk, and developing options that are potentially more sustainable. The process of adopting LMUs is presented and discussed as the basis from which to evaluate the sustainability of land use practices.

Keywords: environment, extension, farm management, land management units, land use, soil, survey, sustainability

\section{The issues}

In a national mail survey to identify household- and farm-level sustainable technologies and management practices (Rauniyar et al. 1998), only $8 \%$ of the farmer respondents rated environmental factors essential for the long-term viability of their farm business (Table 1). In contrast, $70 \%$ of the respondents rated economic and financial factors as being important to the longterm viability of the farm business, which is not surprising when one considers the low level of cash surplus for sheep and beef and dairy farming households. In 1998, the net cash surplus for the farming household represented by the all-class weighted average sheep and beef farm was $\$ 3440$, and $\$ 9497$ for the average dairy farm (A. Barber pers. comm.).

The survey respondents established only a weak linkage between productivity, environmental issues, and the long-term viability of the farm business. There could be a range of reasons for this. There may be few farms with real environmental issues that impact on longterm viability. Alternatively, action may have already been taken to successfully manage perceived environmental risks, or the level of environmental risk is considered to be small in relation to other risks. Another

Table 1 Essential factors identified by the survey farmers for the long-term viability of farm business (\% farmers responding).

\begin{tabular}{|c|c|c|c|c|c|c|}
\hline \multirow[t]{2}{*}{ Issues } & \multicolumn{4}{|c|}{ Farm Type } & \multirow{2}{*}{$\begin{array}{l}\text { Overall \% } \\
\text { response }\end{array}$} & \multirow{2}{*}{$\begin{array}{c}\text { Chi-square } \\
\text { d.f }=3\end{array}$} \\
\hline & Dairy & $\begin{array}{l}\text { Sheep, beef, } \\
\text { deer }>500 \text { su }\end{array}$ & $\begin{array}{l}\text { Sheep, beef, } \\
50-500 \text { su deer }\end{array}$ & $\begin{array}{l}\text { Hobby } \\
<50 \text { su }\end{array}$ & & \\
\hline Economic/Financial & 82 & 88 & 65 & 51 & 70 & $31.6 * * *$ \\
\hline Social & 48 & 50 & 22 & 30 & 37 & $18.5^{* * *}$ \\
\hline Productivity & 30 & 30 & 36 & 41 & 34 & 3.1 (ns) \\
\hline Environmental & 1 & 3 & 11 & 14 & 8 & $12.4^{* * *}$ \\
\hline
\end{tabular}


explanation is that the respondents did not identify or appreciate the effect of their management on wider environmental goals or how market access may be affected by standards of environmental management.

In a separate phase of the study (Rauniyar et al. 1998), a group of farmers, scientists, policy agents and advisers addressed factors associated with farming sustainably. Working in an exchange forum situation, the participants were able to identify 28 technologies and management practices that were important for achieving the goal of sustainable farming. Of the range of technologies identified, 24 focused on either the soil or water resource of the farm, perhaps reflecting the role that the management of these resources has in shaping farmers' perception of sustainability issues.

This difference in response is not surprising. When working alone, farmers are more likely to limit decisions to aspects that are familiar and that they understand, and which often have short-term production and financial impact. Issues that have broader impact, or about which information and benefit are limited, make for more difficult decision making.

In most pastoral farming businesses, the greatest investment is the land. That should be reason enough for farmers to have a thorough understanding of this resource and the linkage it has to financial performance and sustainability. Yet typically, only superficial consideration is given to the soils of the farm at purchase, or subsequently when policies and management practices are reviewed. Current farm and paddock boundaries are often an arbitrary product of history, with little relationship to the physical landscape. Previous practices have frequently diminished these differences by seeking to impose general stock management policies and management systems.

\section{Soil resources on-farm}

Each farm is a unique mix of natural and managed features that coalesce to create special opportunities, constraints and potentials. While some farmers have effectively recognised differences, there has been little attempt to provide a decision-making format that will assist management of the land resource and the development of sustainable farming practice. Mackay et al. (1999) showed that through obtaining information on each of the units of land on a farm, and understanding how each behaves, farmers were able to demonstrate how economic performance could be enhanced and environmental outcomes improved. We contend that land users need to change the way they perceive the soil resource of their farm, and that the physical resources of the farm need to be more prominent in decision making. The concept of (LMUs) is an important tool to support that process.

\section{Land Management Units}

The concept of LMUs was developed in a Sustainable Land Management (SLM) project conducted in the Southern North Island (Mackay et al. 1999). LMUs are areas of land that have features that differentiate them, either through potential productivity, or because of limitations to use. For example, soil drainage properties may limit the period of the year that the unit may be grazable by cattle, differences in soil textural properties may provide a high level of robustness to treading when the soil is wet, or aspect may enable early season growth to be fully utilised.

In the SLM project working with community groups associated with two properties, Gwavas Station in Hawke's Bay (978 ha farmed) and Westview in Manawatu (725 ha farmed), LMUs were used as the basis for planning sustainable land management enterprises. For the project, detailed soil maps of the properties were produced, but they proved too detailed for decision making. Areas of similar features were amalgamated into manageable units. An important lesson was demonstrated during this process. Unless land managers are involved in the process of identifying the soil and understand the features and properties involved, they are not in a position to use the information to shape land use policies and practice. To this end, a current project is examining the feasibility of pastoral farmers mapping the soils of their farm as the important first step in compiling LMUs for the properties (Rhodes unpublished data). This project, based in Dannevirke, has the goal of upskilling the farmers and demonstrating an affordable process for defining LMUs.

In the SLM project, consideration of the strengths, weaknesses and the strategic value of individual areas of soils on each property resulted in aggregation into LMUs. The 25 soil types identified on Westview were reduced to eight LMUs, while at Gwavas, six LMUs resulted from the nine soil types initially identified. Each LMU, which was determined by the predominant soils and the potential land uses, featured a unique range of inputs and raised a range of specific environmental and other concerns (Table 2). At Gwavas, topographic features clearly separated the flat high terraces of free-draining soil with a risk of wind erosion, from the rolling poorly drained Poporangi soils. In contrast, at Westview, first impressions were that the upper and lower hill country were one, but subtle and important differences in soil drainage and resilience were identified which enabled new opportunities to be explored.

Through the process of identifying the LMUs on their farms, land users can develop a more effective 
Table 2 Summary of groups findings for selected Land Management Units at Gwavas and Westview farms.

\begin{tabular}{|c|c|c|c|c|}
\hline $\begin{array}{l}\text { PROPOSED LAND } \\
\text { MANAGEMENT UNIT }\end{array}$ & $\begin{array}{l}\text { PREDOMINANT } \\
\text { SOILS }\end{array}$ & $\begin{array}{l}\text { PROPOSED ALTERNATIVE } \\
\text { LAND USES }\end{array}$ & INPUTS & CONCERNS \\
\hline \multicolumn{5}{|l|}{ Gwavas } \\
\hline $\begin{array}{l}\text { IMPROVED HIGH } \\
\text { TERRACES }\end{array}$ & Takapau & $\begin{array}{l}\text { - Technosystem bulls } \\
\text { - process cropping }\end{array}$ & $\begin{array}{l}\text { - shelter and tree planting } \\
\text { - irrigation } \\
\text { - improved grass species for } \\
\text { drought and production } \\
\text { - fencing of riparian zones }\end{array}$ & $\begin{array}{l}\text { - weeds, especially ragwort, thistle } \\
\text { (use thistle parasite) } \\
\text { - wind erosion after cultivation, } \\
\text { compaction, cadmium accumulation } \\
\text { - water availability and quality, } \\
\text { nitrate leaching } \\
\text { - bloat }\end{array}$ \\
\hline $\begin{array}{l}\text { UNIMPROVED HIGH } \\
\text { TERRACES }\end{array}$ & Takapau & $\begin{array}{l}\text { - dairy, intensive beef } \\
\text { - deer, drystock, sheep } \\
\text { - grapes } \\
\text { - flowers } \\
\text { - horticulture } \\
\text { - crops, grains, peas and } \\
\text { vegetables }\end{array}$ & $\begin{array}{l}\text { - heavy capital dressings } \\
\text { - possible chemical plough and } \\
\text { crop before reseeding pasture } \\
\text { - higher producing grass species, } \\
\text { bio-control for gorse } \\
\text { - shelter } \\
\text { - tree planting } \\
\text { - fencing of riparian zones } \\
\text { - irrigation if water available }\end{array}$ & $\begin{array}{l}\text { - weed control but consider leaving } \\
\text { weeds in riparian zone } \\
\text { - pest control - rabbits, possums and } \\
\text { grass grub and porina } \\
\text { - cow shed effluent disposal } \\
\text { - wind erosion after cultivation } \\
\text { - nitrate leaching, silt runoff after } \\
\text { rain, pesticides in water } \\
\text { - investment cost } \\
\text { - water availability, reticulation }\end{array}$ \\
\hline WETTER ROLLING & Poporangi & $\begin{array}{l}\text { - beef and sheep mix } \\
\text { - deer } \\
\text { - forage crops } \\
\text { - peas and vegetables }\end{array}$ & $\begin{array}{l}\text { - soil tests, capital fertiliser } \\
\text { - P \& K } \\
\text { - new pasture grasses and } \\
\text { clovers } \\
\text { - shelter, woodlots } \\
\text { - fencing off watercourses, } \\
\text { possible drainage }\end{array}$ & $\begin{array}{l}\text { - pugging of soils } \\
\text { - weeds, (thistles), pests (grass grub) } \\
\text { - sedimentation of watercourses } \\
\text { - nutrient loading, faecal } \\
\text { contamination of waterways }\end{array}$ \\
\hline \multicolumn{5}{|l|}{ Westview } \\
\hline $\begin{array}{l}\text { LOWER HILL } \\
\text { COUNTRY }\end{array}$ & $\begin{array}{l}\text { Makotuku } \\
\text { Matanganui } \\
\text { Halcombe }\end{array}$ & $\begin{array}{l}\text { - sheep only } \\
\text { - cattle in summer }\end{array}$ & $\begin{array}{l}\text { - } \text { subdivision } \\
\text { - drainage } \\
\text { - increase stock numbers } \\
\text { - reseeding } \\
\text { - shade and shelter trees } \\
\text { - increased fertiliser } \\
\text { - increased labour } \\
\text { - stock water }\end{array}$ & $\begin{array}{l}\text { - risk from more intensive systems } \\
\text { - soil damage from cattle and high } \\
\text { stocking rates } \\
\text { - run-off into farm streams } \\
\text { - slump and surface erosion } \\
\text { - no deer }\end{array}$ \\
\hline $\begin{array}{l}\text { UPPER HILL } \\
\text { COUNTRY }\end{array}$ & $\begin{array}{l}\text { Whetukura } \\
\text { Kiwitea } \\
\text { Dannevirke }\end{array}$ & $\begin{array}{l}\text { - sheep and beef } \\
\text { - deer }\end{array}$ & $\begin{array}{l}\text { - shade and shelter trees } \\
\text { - increased fertiliser } \\
\text { - increased labour } \\
\text { - fencing of riparian zones }\end{array}$ & $\begin{array}{l}\text { - compaction } \\
\text { - porina } \\
\text { - weeds } \\
\text { - water quality }\end{array}$ \\
\hline
\end{tabular}

understanding of the potentials, constraints and issues that will drive their decision making for the next century. Importantly, through a stronger appreciation of the soil resource of the farm and utilising this in the development of the farm business plan, a more robust and sustainable approach to business development will have been initiated.

\section{Developing meaningful land use polices and enterprises}

The process for using the knowledge developed about the LMUs to shape future policies is illustrated by the approach taken in the SLM project (Mackay et al. 1999). The community group at Gwavas developed three pastoral and cropping options. At Westview four major pastoral management options and a number of forestry scenarios were evolved.

\section{Pastoral land use}

Both Westview and Gwavas community groups established that "No one option is right for the farm", rather each farm is a unique composition of LMUs, issues and constraints. Some people placed high value on incorporating diversity into their working and farming policies, while others appreciated simplicity and working with familiar technology. By recognising the potentials and constraints of each area of the farm, a range of complimentary options was considered for the farm as a whole. This allowed production potential to be maximised, while minimising the likelihood of adverse environmental, social and economic effects.

At Gwavas, no one LMU obviously drove strategic land use decisions. The Takapau soils represented 51\% of the farmed area, but their spread and separation around the farm limited their usefulness. In contrast, at Westview, the lower hill country area shaped the basic 
farm options and enterprises. On this property, feed quality is critical for achieving high livestock performance in a summer moist environment, and cattle were identified as an important component of any farming system for the property. However, on several of the LMUs the risk, and long-term impact, of soil damage in winter and early spring was considered to be high. The period of critical constraint for a breeding cow herd was from pre-calving to mating and the most resilient LMU available limited the herd size to 250 .

An evaluation of the range of options on both properties involved in the study, and their combinations for the level of achievable performance, the fit with the level and pattern of pasture production, and estimation of the relative financial outcome was undertaken. The computer-based modelling software package Stockpol (Stockpol 1996) was used to represent the features of each of the LMUs and to facilitate the integration of each of the potential pastoral land use enterprises and policies into a whole-farm system.

In addition to the current enterprise mix (status quo), alternative systems were evolved in response to the values of the community group members. This process reflected issues of environmental and market risk, profitability, capital investment required for establishment, income diversification, biological fit and balance of complementary classes of stock, complexity of management, and level of skills and knowledge. Underpinning this exercise was a sound working knowledge of the farms' soil resources.

At Gwavas, the four options were the status quo of 4060 ewes (120\% lambing) finishing all lambs at 14.5$15 \mathrm{~kg}$ carcass weight, a 186-cow beef herd, and purchasing and finishing 700-900 18-30-month bulls and steers. Option 1 included a higher performance flock of 3700 ewes (160\% lambing) and finishing 920 18-30-month bulls. Option 2 involved a 3000-ewe high performance flock, a breeding unit of 440 hinds finishing to slaughter at 12-18 months of age, and intensive cropping with 250 ha in crop and 168 ha in winter greenfeed finishing 920 18-22-month bulls and wintering dairy cow grazers.

The options at Westview included the status quo of a 4600 -ewe breeding flock (110-115\% lambing) selling store and finishing lambs, 290-cow herd selling weaners, and a breeding unit of 160 hinds. Option 1 was a high performance flock of 3500 ewes ( $130 \%$ lambing) finishing lambs to $15 \mathrm{~kg}$ carcass weight, a 200 -cow herd selling progeny at 18-20 months, and a 150 -head venison unit. Option 2 featured fewer sheep - 2600 ewes, 230 cows selling progeny as yearlings, and a 600 -deer breeding unit. The third option included a 3600-ewe flock, 140cow herd selling yearlings, a 150 -head venison unit and a 680 -ewe merino flock grazing the high country.
While one enterprise option was potentially less profitable than the status quo at Westview, other options were modelled as being more profitable (Table 3). All three options were judged to comprise land use practices that were more sustainable than current practice. The study at Gwavas indicated that each of the two alternative pastoral systems were potentially more profitable and featured more sustainable soil and water management practices than the status quo, highlighting that the goals of improved profitability and environmental outcomes are not in conflict.

Table 3 Gross Margin Comparison (\$/ha) for Enterprise Combinations.

\begin{tabular}{lcccc}
\hline & Status quo & Option 1 & Option 2 & Option 3 \\
\hline Gwavas & $\$ 445$ & $\$ 556$ & $\$ 635$ & - \\
Westview & $\$ 488$ & $\$ 469$ & $\$ 509$ & $\$ 494$ \\
\hline
\end{tabular}

\section{Conclusions}

The process of adopting LMUs as the basis from which to evaluate the sustainability of land use practices has been demonstrated to be effective in a SLM project. The results have improved understanding by land users of critical soil properties and the interaction of pastoral farming activities with the environment, and recognition that some of the current mix of enterprise and management actions are potentially sustainable.

The SLM project demonstrated that even in comparatively complex landscapes, LMUs provide a systematic basis from which opportunities can be considered and issues affecting sustainable management of the soil resource of the farm can be evaluated.

Identifying critical soil properties, mapping soils and establishing LMUs requires a level of skill and confidence beyond the normal experience of farmers. In the Gwavas and Westview study, pedologists initially led this process. Elsewhere, some Regional Councils provide a service mapping Land Use Capability classes, with a focus on identifying areas targeted for soil conservation practices. Based on the interim results of the Dannevirke project, most farmers with some help, have the ability to compile an effective soil map and to use the soils information to derive LMUs. This provides an objective basis for farmers to integrate soils into their decision making. The additional skills needed could be developed through existing industry-based training modules, and would empower farmers to more effectively integrate more sustainable management practices into their everyday decision making.

In the era of business planning, the chance to provide farmers with the tools and skills to integrate knowledge 
about their farm's greatest resource - the soil - into their vision, values, competitive advantage and strategic business goals seems like an opportunity not to be missed.

\section{REFERENCES}

Mackay, A.D.; Lambert, M.G.; Krausse, M.K.; Rhodes, A.P.; Wallace, B.D.; Scott, J.S. 1999. A farmerbased approach to sustainable land management by matching enterprises with land capabilities and managing environmental impacts. Meat New Zealand Project 94 PR 132/3.3

Rauniyar, G.P.; Parker, W.J. 1998. Constraints to farm level adoption of new sustainable technology and management practices in New Zealand pastoral agriculture. MAF Policy technical paper 1998/3.

Rhodes, A.P.; Mackay, A.D.; Wilde, H.; Palmer, A.; Cooper, G. 1999. Farmer Training For Land Resource Assessment. Interim report, March 1999. Project funded by AGMARDT and Horizons.mw.

Stockpol decision support software; AgResearch; Version 4.33. 
